\title{
Comparison of Phosphorus Extraction from Sludge Incinerated Bottom Ash and Sludge Incinerated Fly Ash Using Sulfuric Acid
}

\author{
Lingfang $\mathrm{Xu},{ }^{1, \dagger}$ Ying Chen, ${ }^{1,2, \dagger}$ Min Liu, ${ }^{1,2, *}$ and Xiong Fu ${ }^{1}$ \\ ${ }^{1}$ College of Architecture and Environment, Sichuan University, Chengdu, China. \\ ${ }^{2}$ Sino-German Centre for Water and Health Research, Chengdu, China.
}

Received: December 21, 2019

Accepted in revised form: April 26, 2020

\begin{abstract}
Ashes from excess sludge incineration plants contain a high content of phosphorous (P). Taking $\mathrm{H}_{2} \mathrm{SO}_{4}$ as an extraction agent, this study investigated the P recovery potential of sludge incinerated bottom ash (SIBA) and sludge incinerated fly ash (SIFA) from an incineration plant in China. The results showed that P contents of SIBA and SIFA were 70,200 and $9,100 \mathrm{mg} / \mathrm{kg}$, respectively, which indicated that SIBA had greater recycling potential of $\mathrm{P}$. The reaction temperature played a significant role in $\mathrm{P}$ extraction process. The extraction yields were $99 \%$ and $98 \%$ from SIBA and SIFA at $45^{\circ} \mathrm{C}$, and it also demonstrated that raising the temperature could extract $\mathrm{P}$ almost entirely from both SIBA and SIFA. Considering the cost-effective consumption, $\mathrm{P}$ extraction yields obtained from SIBA and SIFA were $89 \%$ and $90 \%$ under the optimized conditions (reaction time of $30 \mathrm{~min}, \mathrm{H}_{2} \mathrm{SO}_{4}$ dosage of $12 \mathrm{mmol}$, the reaction temperature of $25^{\circ} \mathrm{C}$, and a ratio of leachate/solid ash of 35). The contents of $\mathrm{Cu}, \mathrm{Zn}, \mathrm{Pb}, \mathrm{Cr}$, and $\mathrm{Ni}$ in the leaching solution from SIBA and SIFA met the requirements of U.S. AAPFCO and Chinese national regulatory of $\mathrm{P}$ fertilizer production. Based on an approximate estimate, a total of $6.27 \mathrm{~kg}$ of $\mathrm{P}$ would be extracted from $1,000 \mathrm{~kg}$ of sludge (about $6.25 \mathrm{~kg}$ of $\mathrm{P}$ was extracted from SIBA and $0.02 \mathrm{~kg}$ of $\mathrm{P}$ was extracted from SIFA). It would provide a reference for the recovery of $\mathrm{P}$ from sludge incinerated ash worldwide.
\end{abstract}

Keywords: chemical method; leaching toxic metals; sludge incinerated bottom ash; sludge incinerated fly ash

\section{Introduction}

W ITH THE ACCELERATION of the urbanization process, the discharge of sewage is increasing each year in China. Meanwhile, excess sludge had been produced along with sewage treatment (Kurt et al., 2008). It could be predicted that the excess sludge production would exceed 70 million tons (moisture content $80 \%$ ) by 2020 (Yang et al., 2015; Li et al., 2018). Most phosphorus (P) had transferred into the excess sludge. The mass ratio of total $\mathrm{P}$ in excess sludge reached up to $3.7 \%$, with an average of $2.2 \%$ (Saleh et al., 2018). Therefore, excess sludge was considered as the largest secondary P resource all over the world (Herzel et al., 2016). Moreover, large amount of excess sludge with toxic substances will cause environmental impact if the excess sludge is not properly treated (Dong et al., 2013; Mahon et al., 2017). This prompts us to find a high-efficiency way to dispose of the excess sludge.

Although incineration consumed more costs for construction and energy than other methods, it was a well-proven

*Corresponding author: College of Architecture and Environment, Sichuan University, Chengdu 610065, China. Phone: +86 13880762097; Fax: +86 (028) 85460916; E-mail: liuminscu@163.com

${ }^{\dagger}$ These two authors contributed equally to this work. technology of sludge disposal method that was adopted in many countries (Ottosen et al., 2013). The proportion of burning sludge in waste incineration plants could vary from country to country. Almost all of the municipal and industrial wastewater sludge was incinerated in the Netherlands and Switzerland (Milieu et al., 2010). Incineration was also a common method adopted in Japan, which counted for $62.7 \%$ of all sludge in the country (Lundin et al., 2004). While, only $0.36 \%$ of municipal and industrial wastewater sludge was incinerated in China (Yang et al., 2015). Actually, incineration has many advantages, such as its small floor area, a high degree of harmlessness, unaffected operating conditions, and stable sludge incinerated ash (Mattenberger et al., 2008; Karamalidis and Voudrias, 2009; Murakami et al., 2009). Incineration is the method that can meet the Chinese national standards (CN-GB, 2009), which sets the threshold limits of less than $60 \%$ moisture content of sludge requirement to enter the landfill in China. Incineration can greatly reduce the volume of excess sludge, which avoids the problem of huge land resource occupation and environmental pollution. With the increase of sludge production and the more strict requirements set by the Chinese government for environment, the incineration technology dealing with municipal and industrial wastewater sludge shows a great potential in sludge disposal. 
Incineration is a heat treatment process using high-reaction temperature to treat wastes under aerobic conditions. A considerable amount of sludge incinerated ash is produced in the process (Huang et al., 2018). When the fluidized bed incinerator reaction temperature is $950^{\circ} \mathrm{C}$, organic $\mathrm{P}$ in $\mathrm{P}$-accumulating bacteria is completely converted into inorganic $\mathrm{P}$ by the thermal decomposition temperatures (Li et al., 2015). In the incineration process, there are usually two flows of $\mathrm{P}$. One flow is the combustion products of excess sludge that remained in an incinerator. This portion is called sludge incinerated bottom ash (SIBA). It is mainly composed of inorganic minerals that do not participate in physical and chemical reactions in the sludge. The other flow of $\mathrm{P}$ is the particulate matter in the flue gas trapped by the dust collector, mainly composed of silicate and calcium, and other metal elements (Yvonne et al., 2018). This portion is called sludge incinerated fly ash (SIFA). Further exploration into simple $\mathrm{P}$ extraction methods should be performed separately from SIBA and SIFA.

In recent years, $\mathrm{P}$ recovery from sludge incinerated ash has become a hot issue. Various methods can extract $\mathrm{P}$ from SIBA, including thermochemical (Adam et al., 2009; Nowak et al., 2011), electrodialytic (Ottosen et al., 2016; Parés et al., 2017), and wet chemical methods (Xu et al., 2012; Lee and Kim, 2017; Fang et al., 2018). Because of high-efficiency and low energy consumption, the wet chemical extraction has become the most popular method recently. The wet chemical method refers to extract $\mathrm{P}$ from the material by extraction agents to obtain P-rich solution, which is the most concerned by scholars (Meng et al., 2018; Wang et al., 2018). After that, the P-rich solution can be subsequently used in the general phosphate fertilizer production process. Thus, properly choosing the right extraction agents under a good condition is worth noting.

The composition of ashes and the extract conditions of excess sludge incineration varies with different wastewater source. Therefore, choosing a proper extraction agent is critical for a successful $\mathrm{P}$ extraction using wet chemical methods. There are many different types of agents, such as $\mathrm{H}_{2} \mathrm{SO}_{4}$ (Ottosen et al., 2016; Liang et al., 2019), $\mathrm{HCl}(\mathrm{Xu}$ et al., 2012), $\mathrm{HNO}_{3}$ (Sano et al., 2012; Gorazda et al., 2016), and oxalic acid (Liang et al., 2019). Among these extractants, $\mathrm{H}_{2} \mathrm{SO}_{4}$ is widely used because of its low cost and highefficiency extraction yield. Atienza-Martinez et al. (2014) used $\mathrm{H}_{2} \mathrm{SO}_{4}$ as the extraction agent, and the extraction yield of $\mathrm{P}$ from SIBA was $85 \%$ after $2 \mathrm{~h}$ reaction. Donatello et al. (2010) extracted $\mathrm{P}$ from SIBA with $\mathrm{H}_{2} \mathrm{SO}_{4}$ and obtained a $\mathrm{P}$ extraction yield more than $80 \%$. Based on these facts, $\mathrm{H}_{2} \mathrm{SO}_{4}$ was selected as the extraction agent in this study. The factors affecting extraction of $\mathrm{P}$ by $\mathrm{H}_{2} \mathrm{SO}_{4}$ include reaction time, $\mathrm{H}_{2} \mathrm{SO}_{4}$ dosages, reaction temperature, and ratio of leachate/ solid ash (Shiba and Ntuli, 2017; Fang et al., 2018). Nevertheless, previous studies only focused on the extraction from SIBA. To the best of our knowledge, there was little literature regarding P extraction from SIFA. Yvonne et al. (2018) only demonstrated that the leaching solution of SIBA and SIFA was harmless to terrestrial insects and marine organisms, but did not mention $\mathrm{P}$ extraction from SIFA.

The aim of this study was to extract $P$ from SIBA and SIFA using $\mathrm{H}_{2} \mathrm{SO}_{4}$ as an extraction agent, investigate the content of $\mathrm{P}$ in SIBA and SIFA, and discuss the feasibility of $\mathrm{P}$ recovery from SIBA and SIFA. In this study, the initial contents of each component and physical properties of SIBA and SIFA were analyzed. Extraction experiments with different reaction time, $\mathrm{H}_{2} \mathrm{SO}_{4}$ concentration, reaction temperature, and ratio of leachate/solid ash were conducted both on SIBA and SIFA. The contents of metals in the leaching solution were analyzed to determine whether it is suitable for agricultural uses. Combined with $\mathrm{P}$ extraction yield, the potential of $\mathrm{P}$ recovery from the wet sludge was approximately estimated in this study.

\section{Materials and Methods}

\section{Source of SIBA and SIFA samples}

The experimental samples (SIBA and SIFA) were obtained from an excess sludge incineration plant in Sichuan province, China. Before testing, the collected samples of SIBA and SIFA were dried at $105^{\circ} \mathrm{C}$ for $2 \mathrm{~h}$. The samples were cooled to room temperature in a drying dish and then weighed for the experiment.

\section{$P$ extraction and experimental design of influencing factors}

The same extracting process was applied to all extracting experiments. The sample of SIBA (or SIFA) and $\mathrm{H}_{2} \mathrm{SO}_{4}$ solution were added to a $250 \mathrm{~mL}$ conical flask. Then the flask was rotated at $150 \mathrm{rpm}$ for a period of reaction time under different reaction temperatures. After stirring, the mixture was filtered with a $0.45 \mu \mathrm{m}$ filter so that the leaching solution and solid residue of SIBA (or SIFA) were obtained. The detailed parameters of extracting experiments were selected based on lots of pre-experiments about SIBA and SIFA. The specific condition parameters were different leachate/solid ash ratios $\left(25,35\right.$, and 45), $\mathrm{H}_{2} \mathrm{SO}_{4}$ dosages $(9,10,11,12$, and $13 \mathrm{mmol})$, reaction time $(5,10,15,20,30,45$, and $60 \mathrm{~min})$, and temperatures $\left(25^{\circ} \mathrm{C}, 35^{\circ} \mathrm{C}\right.$ and $\left.45^{\circ} \mathrm{C}\right)$. The study was performed as above to obtain the optimal conditions.

\section{Calculation methods}

Three sets of parallels were performed for each experiment, and the results were averaged. $\mathrm{P}$ extraction yield $\left(X_{\mathrm{P}}\right)$ from SIBA (SIFA) was calculated in Equation (1).

$$
X_{\mathrm{P}}=\frac{V * C_{\mathrm{P}}}{\omega_{\mathrm{P}} * \mathrm{M}} * 100 \%
$$

where $\omega_{\mathrm{P}}$ is the mass ratio of $\mathrm{P}$ in the SIBA (SIFA) sample before extraction; $\mathrm{M}(\mathrm{mg})$ is the quality of the sample before extraction; $V(\mathrm{~L})$ is the volume of the leaching solution; $C_{\mathrm{P}}(\mathrm{mg} / \mathrm{L})$ is the $\mathrm{P}$ concentration of the leaching solution.

\section{Analytical methods}

For determining the chemical compositions of SIBA and SIFA samples, the samples were acid digested using $\mathrm{HCl}$, $\mathrm{H}_{2} \mathrm{SO}_{4}, \mathrm{HNO}_{3}$, and aqua regia (Biswas et al., 2009), then followed by inductively coupled plasma optical emission spectrometer (ICP-OES) analysis (Avio 200; PerkinElmer). Morphology of SIBA and SIFA was determined by using an SEM observation (JSM-7500F; Jeol, Japan). After P extraction, the leaching solution samples were filtered through $0.45-\mu \mathrm{m}$ membrane filters. The concentration of $\mathrm{P}$ in the 
leaching solution was measured by a molybdenum-blue ascorbic acid method (APHA et al., 2005). The metals in the leaching solutions were measured by ICP-OES analysis after P extraction from SIBA and SIFA (5110; Agilent Technology).

\section{Results and Discussion}

\section{Elemental compositions of SIBA and SIFA}

The elemental compositions of SIBA and SIFA are shown in Table 1. As shown in Table 1, P level in SIBA was $70,200 \mathrm{mg} / \mathrm{kg}$, equivalent to $32 \% \mathrm{P}_{2} \mathrm{O}_{5}$ in phosphate ores, which was higher than those measured by most of the other scholars, such as Kleemann et al. (2017), Ottosen et al. (2013), Fang et al. (2018), and Biswas et al. (2009). Furthermore, P contents in SIBA could be compared with $\mathrm{P}$ contents of phosphate ore used for superphosphate production $(>30 \%$ $\mathrm{P}_{2} \mathrm{O}_{5}$ ) (Xu et al., 2014; Nie et al., 2019). It indicated that the SIBA had a great potential for $\mathrm{P}$ recovery. The $\mathrm{P}$ level in SIFA was $9,100 \mathrm{mg} / \mathrm{kg}$ as shown in Table 1 . In addition to recovering $\mathrm{P}$ from SIBA, it was also worth to recover P from SIFA as the phosphate rock resources were exhausted.

The Ca level in SIBA and SIFA were 43,750 and $311,191 \mathrm{mg} / \mathrm{kg}$, respectively, which counted for seven times in SIFA than that in SIBA. The large difference of Ca contents between those two may affect $P$ extraction process from SIBA and SIFA. Especially, Ca may play an important role in reaction with $\mathrm{H}_{2} \mathrm{SO}_{4}$ and SIFA. S content of $81,003 \mathrm{mg} / \mathrm{kg}$ made $\mathrm{S}$ the second most abundant element in SIFA. While, $\mathrm{S}$ was not detected in SIBA. It could be considered to recover $S$ from SIFA in the future.

In addition, SIBA and SIFA contained six common elements of $\mathrm{P}, \mathrm{Ca}, \mathrm{Fe}, \mathrm{K}, \mathrm{Zn}$, and $\mathrm{Cu}$. Figure 1 demonstrated the proportion distribution of these six elements in SIBA and SIFA respectively. Overall, for the total $\mathrm{P}$ content in the sludge incinerated ash, SIBA accounted for $88 \%$ and SIFA accounted for $12 \%$, as shown in Fig. 1. It illustrated that most of P remained in the sludge had entered into the SIBA during the sludge incineration process, while a small part of $P$ had entered into the SIFA as fine particles. It further indicated that SIBA had a greater possibility of $\mathrm{P}$ extraction than SIFA. In contrast to the P distri-

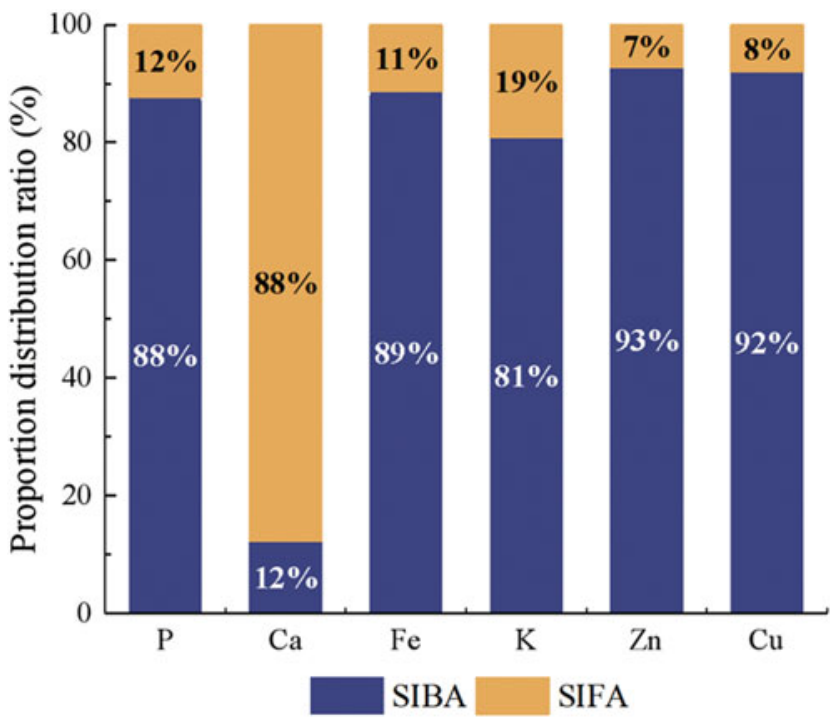

FIG. 1. Proportion distribution of common elements between SIBA and SIFA. SIBA, sludge incinerated bottom ash; SIFA, sludge incinerated fly ash.

bution, $\mathrm{Ca}$ accounted for $88 \%$ in SIFA and $12 \%$ in SIBA. Ca and $\mathrm{P}$ showed completely different distribution patterns when incinerated. Most of the Ca was accompanied by small particles into the SIFA, which indicated that the Ca-P compounds may be rare in SIBA and SIFA. Other elements such as $\mathrm{Fe}, \mathrm{K}, \mathrm{Zn}$, and $\mathrm{Cu}$ all accounted for more than $80 \%$ in SIBA, which were similar to P. It illustrated that these elements were more likely to react with $\mathrm{P}$ to form metals-P compounds. From the perspective of resource recovery, SIBA was more valuable to recycle than SIFA.

\section{Physical properties of SIBA and SIFA}

Figure 2a shows the surface morphology of SIBA. Most particles were stacked together to form a structure with a rough and porous surface. Figure $2 \mathrm{~b}$ shows the surface morphology of SIFA. Most particles were connected together to form a structure with a relatively smooth surface. The

Table 1. Elemental Compositions and Contents of Sludge Incinerated Bottom Ash, SLudge INCINERATEd Fly Ash, AND SAMPLES IN OTHER REPORTS

\begin{tabular}{lcccccccc}
\hline $\begin{array}{l}\text { Elements, } \\
m g / k g\end{array}$ & $\begin{array}{c}\text { SIBA this } \\
\text { study }\end{array}$ & $\begin{array}{c}\text { SIFA this } \\
\text { study }\end{array}$ & $\begin{array}{c}\text { Kleemann et al. } \\
(2017)\end{array}$ & $\begin{array}{c}\text { Ottosen et al. } \\
(2013)\end{array}$ & $\begin{array}{c}\text { Fang et al. } \\
(2018)\end{array}$ & $\begin{array}{c}\text { Biswas et al. } \\
(2009)\end{array}$ & $\begin{array}{c}\text { Xu et al. } \\
(2014)\end{array}$ & $\begin{array}{c}\text { Nie et al. } \\
(2019)\end{array}$ \\
\hline $\mathrm{P}$ & 70,200 & 9,100 & 71,610 & 69,900 & 35,000 & 88,000 & 66,148 & 69,160 \\
$\mathrm{Ca}$ & 43,750 & 311,191 & 143,410 & - & 68,200 & 56,500 & 344,286 & 339,714 \\
$\mathrm{Fe}$ & 43,167 & 5,522 & 29,924 & 15,700 & 158,200 & 52,100 & 980 & 4,725 \\
$\mathrm{~K}$ & 28,083 & 6,634 & 8,605 & - & 29,000 & - & 705 & - \\
$\mathrm{S}$ & - & 81,003 & 12,664 & - & 16,100 & - & 1,320 & - \\
$\mathrm{Al}$ & 30,425 & - & 28,796 & 67,000 & 61,200 & 60,400 & 1,085 & 4,685 \\
$\mathrm{Mg}$ & 10,525 & - & 16,106 & - & 9,300 & 19,300 & 19,380 & 7,080 \\
$\mathrm{Zn}$ & 2,091 & 162 & 3,114 & 1,700 & 2,198 & 763 & - & - \\
$\mathrm{Cu}$ & 652 & 57 & 1,225 & 540 & 839 & 715 & - & - \\
$\mathrm{Ti}$ & - & 663 & - & - & 3,300 & - & - & - \\
$\mathrm{Cr}$ & 172 & - & 79 & - & 590 & - & - & - \\
$\mathrm{Ni}$ & 97 & - & 95 & 29 & 85 & - & - & 240 \\
$\mathrm{~Pb}$ & 56 & - & 660 & 85 & 97 & - & - & 27 \\
\hline
\end{tabular}

“_”, undetected; “-_,, not involved.

SIBA, sludge incinerated bottom ash; SIFA, sludge incinerated fly ash. 
FIG. 2. (a) Surface morphology of the SIBA sample and (b) surface morphology of the SIFA sample.
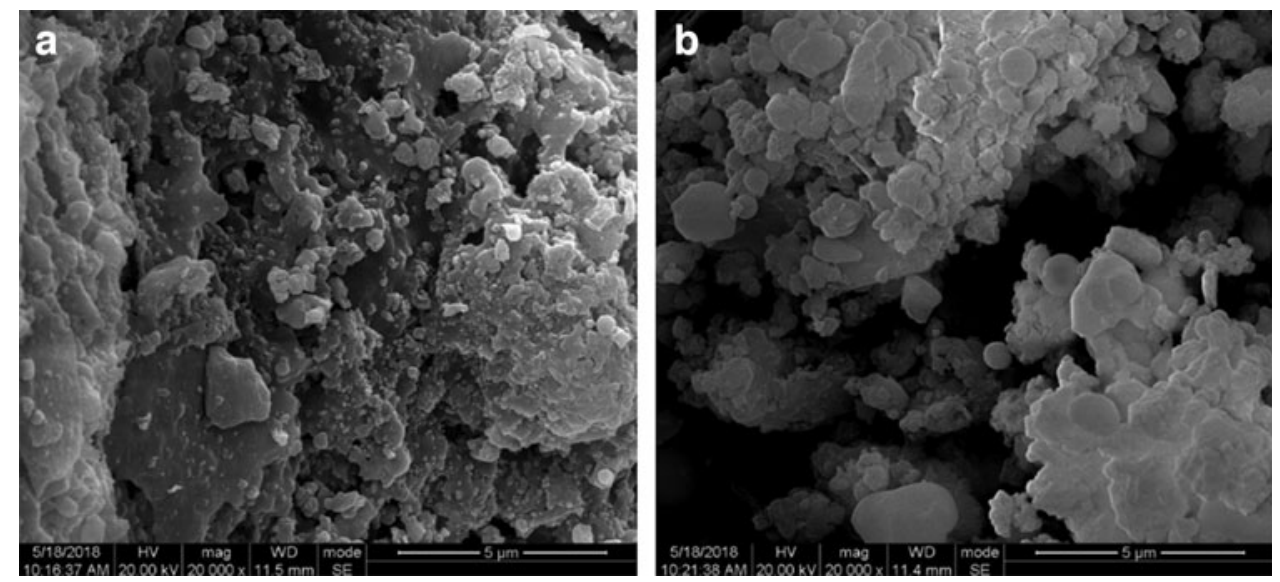

difference in surface morphology between SIBA and SIFA may affect $P$ extraction of the two samples.

\section{Effect of $P$ extraction conditions for SIBA and SIFA}

Effect of reaction time on the extraction efficiency of $P$.

$P$ was extracted from SIBA and SIFA samples using $12 \mathrm{mmol} \mathrm{H}_{2} \mathrm{SO}_{4}$ at a ratio of leachate/solid ash of 45 under $25^{\circ} \mathrm{C}$ for a range of reaction time $(5,10,15,20,30,45$, and $60 \mathrm{~min}$ ). Figure $3 \mathrm{a}$ demonstrated that the longer the reaction time the more $\mathrm{P}$ extracted from the samples. When the reaction time was $5 \mathrm{~min}$, only $47 \%$ of $\mathrm{P}$ was extracted from SIBA. With the elongation of reaction time, the extraction yield rapidly increased, reaching to $91 \%$ at $30 \mathrm{~min}$, and then increased slowly. Nevertheless, the effect was not so significant when testing samples from SIFA. In the first $5 \mathrm{~min}$, the yield of $\mathrm{P}$ extracted from SIFA reached $81 \%$. As the reaction time continued to be increased, $\mathrm{P}$ extraction yield reached $90 \%$ in 30 min. The results indicated that most $\mathrm{P}$ was extracted within $30 \mathrm{~min}$, consistent with other reports (Donatello et al., 2010; Kleemann et al., 2017).

$\mathrm{P}$ extraction yield from SIBA was lower with the same reaction time within $30 \mathrm{~min}$, comparing those with SIFA. Increasing reaction time, both samples had $\sim 90 \%$ of $\mathrm{P}$ extraction yields. Kleemann et al. (2017) obtained an $83 \%$ $\mathrm{P}$ extraction yield at the optimal reaction time of $30 \mathrm{~min}$. Donatello et al. (2010) also obtained an $85 \%$ P extraction yield at $30 \mathrm{~min}$. In this study, the $90 \%$ of $\mathrm{P}$ extraction yield obtained at $30 \mathrm{~min}$ was obviously better than previous studies. The purpose of $\mathrm{P}$ extraction was to produce agricultural fertilizer. If the toxic metal contents in the extraction were higher than required by the National Standards, it would bring potential risks and affect the application of $\mathrm{P}$ extraction technology. Therefore, the contents of metals in the leaching solution were detected in this study, and the results were shown in Table 2 . The heavy metals in the leaching solution at $30 \mathrm{~min}$ reaction time were far lower than the standards of risk-based concentrations for inorganic fertilizers set by Association of American Plant Food Control Officials (U.S. AAPFCO, 2018), and Control standards of pollutants in sludge for agriculture use (CN-GB, 2018). Taking into account that the amount of toxic metals in the leaching solution would increase with increasing reaction time (Fang et al., 2018), the optimum reaction time for $P$ extraction from SIBA and SIFA was designed as $30 \mathrm{~min}$.
Effect of $\mathrm{H}_{2} \mathrm{SO}_{4}$ dosage on the extraction efficiency of $\mathrm{P}$. In this study, $\mathrm{P}$ was extracted from SIBA and SIFA samples using a range of $\mathrm{H}_{2} \mathrm{SO}_{4}$ dosage $(9,10,11,12$, and $13 \mathrm{mmol}$ ) at a ratio of leachate/solid ash of 45 under $25^{\circ} \mathrm{C}$ for $30 \mathrm{~min} . \mathrm{H}_{2} \mathrm{SO}_{4}$ dosage was one of the leading factors controlled the extraction process. As shown in Fig. 3b, the extracted $\mathrm{P}$ gradually increased as $\mathrm{H}_{2} \mathrm{SO}_{4}$ dosage increased from 9 to $12 \mathrm{mmol}$ in SIBA. The same discovery that the extraction yield of $\mathrm{P}$ increased with the increase of $\mathrm{H}_{2} \mathrm{SO}_{4}$ dosage was also demonstrated in other studies (Xu et al., 2012; Ottosen et al., 2013; Kleemann et al., 2017).

Different from SIBA, Fig. 3b shows a steep rise trend of $\mathrm{P}$ concentration in SIFA. It is obvious that higher $\mathrm{H}_{2} \mathrm{SO}_{4}$ dosage could promote the extraction yield of $\mathrm{P}$ from SIFA. When $\mathrm{H}_{2} \mathrm{SO}_{4}$ dosage was below $10 \mathrm{mmol}$, $\mathrm{P}$ extraction yield was less than $20 \%$. While, $\mathrm{P}$ extraction yield reached to $80 \%$ when $\mathrm{H}_{2} \mathrm{SO}_{4}$ dosage was $11 \mathrm{mmol}$, which was about $60 \%$ higher than that of $10 \mathrm{mmol}$. Comparing SIBA with SIFA, P was more easily extracted from SIBA than SIFA with similar experimental conditions. Especially when $\mathrm{H}_{2} \mathrm{SO}_{4}$ dosage was below $10 \mathrm{mmol}$, P extraction yield of SIBA was about four times that of SIFA. From Table 1, it can conclude that $\mathrm{Ca}$ level in SIFA was about seven times as much as that of SIBA. When $\mathrm{H}_{2} \mathrm{SO}_{4}$ dosage was low $(\leq 10 \mathrm{mmol}), \mathrm{H}_{2} \mathrm{SO}_{4}$ might react with the abundant calcium compounds and produced $\mathrm{CaSO}_{4}$. Fang et al. (2018) detected $\mathrm{CaSO}_{4}$ in the production, when using $\mathrm{H}_{2} \mathrm{SO}_{4}$ as a reagent to extract $\mathrm{P}$ from sludge incinerated ash. The occurrences of $\mathrm{CaSO}_{4}$ inhibited the $\mathrm{P}$ extraction process, which leads to low $\mathrm{P}$ yield in SIFA. Increasing $\mathrm{H}_{2} \mathrm{SO}_{4}$ dosage $\left(>10 \mathrm{mmol}\right.$ ), the remaining $\mathrm{H}_{2} \mathrm{SO}_{4}$ reacted with $\mathrm{P}$ compounds in SIFA, so $\mathrm{P}$ extraction yield significantly increased. When $\mathrm{H}_{2} \mathrm{SO}_{4}$ dosage was 12 mmol, $\mathrm{P}$ extraction yield was $91 \%$ in SIFA, the same situation with SIBA. Therefore, the optimum $\mathrm{H}_{2} \mathrm{SO}_{4}$ dosage for SIBA and SIFA was determined to be $12 \mathrm{mmol}$.

Effect of reaction temperature on the extraction efficiency of $P$. Properly controlling the temperature during the extraction process is one of the critical factors to ensure a better result. In this study, $\mathrm{P}$ was extracted from SIBA and SIFA samples respectively, under the same experimental conditions (12 $\mathrm{mmol} \mathrm{H}_{2} \mathrm{SO}_{4}$ dosage, a ratio of leachate/solid $\mathrm{ash}=45,30 \mathrm{~min}$ ), but with various reaction temperature $\left(25^{\circ} \mathrm{C}, 35^{\circ} \mathrm{C}\right.$, and $\left.45^{\circ} \mathrm{C}\right)$. Figure $3 \mathrm{c}$ showed that increasing the reaction temperature could extract more $\mathrm{P}$ from SIBA and 

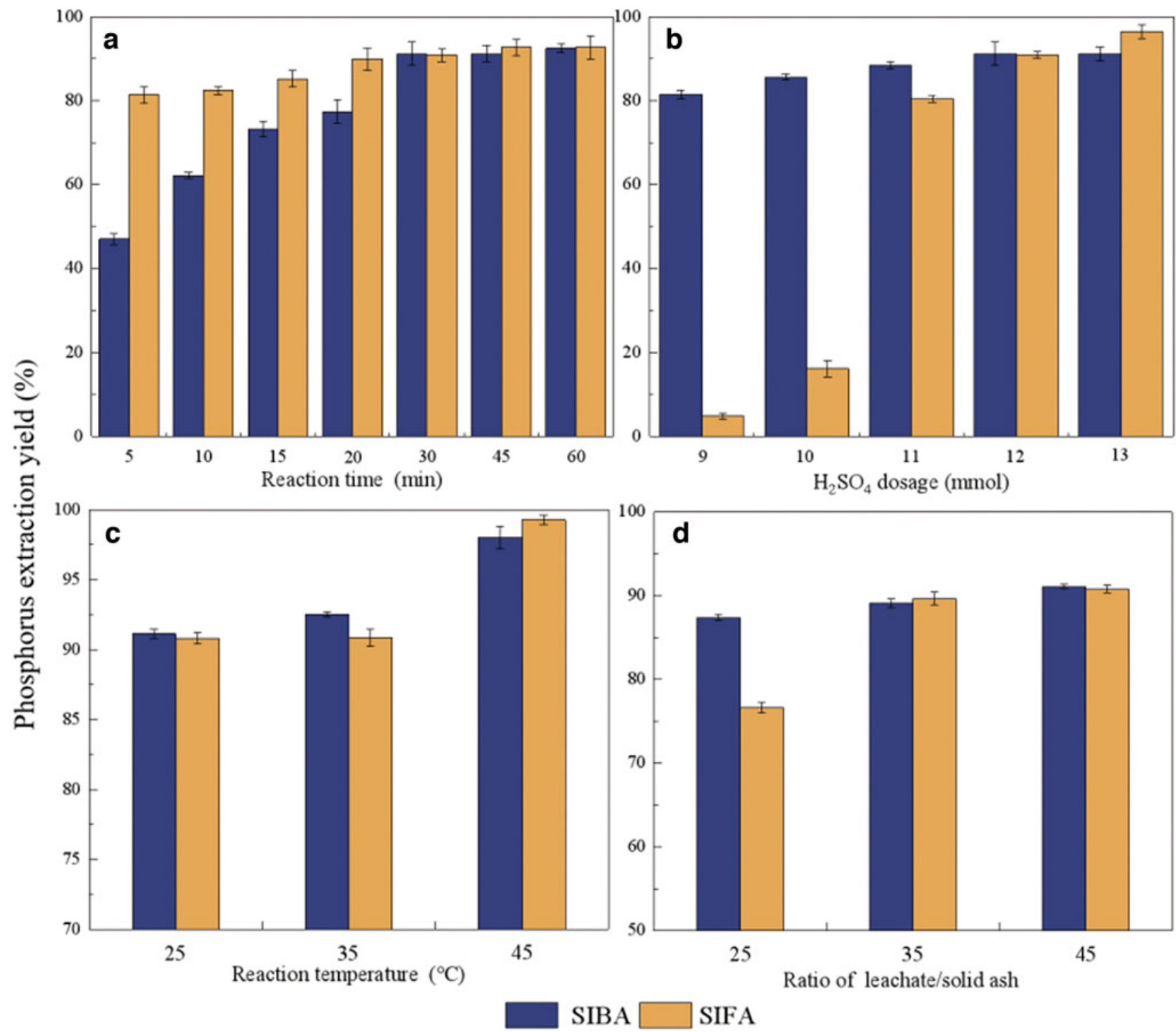

FIG. 3. (a) Effect of reaction time on phosphorous (P) extraction yield by using $\mathrm{H}_{2} \mathrm{SO}_{4}$ from SIBA and SIFA; (b) effect of $\mathrm{H}_{2} \mathrm{SO}_{4}$ dosage on $\mathrm{P}$ extraction yield; (c) effect of reaction temperature on $\mathrm{P}$ extraction yield and (d) effect of ratio of leachate/solid ash on $\mathrm{P}$ extraction yield.

\begin{tabular}{|c|c|c|c|c|}
\hline Elements & $\begin{array}{c}\text { SIBA this } \\
\text { study } \\
(m g / k g)\end{array}$ & $\begin{array}{c}\text { SIFA } \\
\text { this } \\
\text { study } \\
(\mathrm{mg} / \mathrm{kg})\end{array}$ & $\begin{array}{c}\text { U.S. } \\
\text { AAPFCO } \\
\text { (2018) NPK } \\
\text { fertilizer } \\
(\mathrm{mg} / \mathrm{kg} \\
\text { per } 1 \% \\
\left.\mathrm{P}_{2} \mathrm{O}_{5}\right)\end{array}$ & $\begin{array}{l}C N-G B \\
(2018) \\
(m g / k g) \\
\end{array}$ \\
\hline $\mathrm{Zn}$ & 218.75 & 16.17 & 420 & 1,200 \\
\hline $\mathrm{Cu}$ & 187.60 & 28.21 & 一 & 500 \\
\hline $\mathrm{Cr}$ & 7.7 & - & - & 500 \\
\hline $\mathrm{Ni}$ & 3.5 & - & 250 & 100 \\
\hline $\mathrm{Pb}$ & 3.5 & - & 61 & 300 \\
\hline
\end{tabular}

“-”, undetected; “-”, not involved.
SIFA. P extraction yields of SIBA and SIFA were $91 \%$ and $90 \%$, respectively at $25^{\circ} \mathrm{C}$. Increasing reaction temperature to $35^{\circ} \mathrm{C}, 92 \%$ and $91 \%$ of $\mathrm{P}$ were extracted from SIBA and SIFA, respectively. There was almost no difference of $\mathrm{P}$ extraction yields between the two samples when the reaction temperature reached $35^{\circ} \mathrm{C}$. However, almost all of $\mathrm{P}$ was extracted from SIBA and SIFA, 98\% and 99\%, respectively under $45^{\circ} \mathrm{C}$. It indicated that reaction temperature was the most significant factor controlling $\mathrm{P}$ extraction yield than other parameters. Higher reaction temperature could promote the reaction between the $\mathrm{H}_{2} \mathrm{SO}_{4}$ solution and incinerated ash particles. Nevertheless, higher reaction temperature indicated more energy consumed. Therefore, P extraction of SIBA and SIFA were advised to carry out at $25^{\circ} \mathrm{C}$ (Xu et al., 2012; Fang et al., 2018).

Effect of ratio of leachate/solid ash on the extraction efficiency of $P$. Another parameter that needs to be determined is the ratio of leachate and solid ash. In this study, P was 
extracted from SIBA and SIFA samples using various ratios of leahcate and solid ash $(25,35$, and 45$)$, under the same experimental conditions $\left(12 \mathrm{mmol}_{2} \mathrm{SO}_{4}\right.$ dosage, $25^{\circ} \mathrm{C}$, $30 \mathrm{~min}$ ). Figure $3 \mathrm{~d}$ showed that the extraction yield increased smoothly with increasing ratio of leachate/solid ash from SIBA. When the ratios of leachate/solid ash were 25,35 , and 45 , the corresponding $\mathrm{P}$ extraction yields were $87 \%, 89 \%$, and $91 \%$, respectively. A relatively consistent $\mathrm{P}$ extraction yield was obtained regardless of the ratio of leachate/solid ash and the dosages of $\mathrm{H}_{2} \mathrm{SO}_{4} \cdot \mathrm{H}_{2} \mathrm{SO}_{4}$ solution and SIBA particles were fully reacted under the $\mathrm{H}_{2} \mathrm{SO}_{4}$ dosage of $12 \mathrm{mmol}$.

Different from SIBA, P extraction yields were 76\%, 90\%, and $90 \%$ when the ratios of leachate/solid ash in SIFA were 25,35 , and 45 , respectively. P extraction yields of SIBA and SIFA was different when the ratio of leachate/solid ash was 25. As shown in Fig. 2b, SIFA had a relatively smooth surface. This type of structure was resistant to the reaction between the extraction agent and ash because of a lower surface of interphase contact (Gorazda et al., 2016). Therefore, the SIBA with a rough and porous surface showed a higher efficiency to extract $\mathrm{P}$ than SIFA with the relatively smooth surface when the ratio of leachate/solid ash was relatively low.

Nevertheless, the highest ratio of leachate/solid ash was not the most suitable condition for practical engineering because of low $\mathrm{P}$ concentration and production of waste liquid (Xu et al., 2012; Ottosen et al., 2013; Kleemann et al., 2017). To ensure high $\mathrm{P}$ extractions yield and low amount of waste liquid produced, 35 was the optimal ratio of leachate/solid ash of SIBA and SIFA chosen in the actual process. Under optimized conditions ( $30 \mathrm{~min}$ reaction time, $12 \mathrm{mmol} \mathrm{H}_{2} \mathrm{SO}_{4}$ $25^{\circ} \mathrm{C}$, and 35 ratio of leachate/solid ash), P extraction yield of SIBA and SIFA were $89 \%$ and $90 \%$, respectively.

\section{Metals distribution between the leaching solution and solid residue of SIBA and SIFA after $P$ extraction}

During phosphorous extraction process, most $\mathrm{P}\left(\mathrm{PO}_{4}{ }^{3-}\right)$ entered into the leaching solution. At the same time, some metals in SIBA and SIFA moved to the leaching solution too, while others remained in the solid residues of SIBA and SIFA. It was beneficial to explore the distribution of metals for subsequent targeted resource recovery of the leaching solution and solid residue. Therefore, it was necessary to analyze the difference in metals distribution. Under optimal experimental conditions ( $30 \mathrm{~min}$ reaction time, $12 \mathrm{mmol} \mathrm{H}_{2} \mathrm{SO}_{4}$ dosage, $25^{\circ} \mathrm{C}$, and 35 ratio of leachate/solid ash), the metals in the leaching solution from SIBA and SIFA were measured.

Metals distribution between the leaching solution and solid residue of SIBA after $P$ extraction. Metals in the leaching solution from SIBA were measured. Combined with the total amount of each metal in SIBA, the leaching rate of each metal was calculated. Therefore, the distribution of each metal in the leaching solution and residue can be obtained, as shown in Fig. 4.

As shown in Fig. 4, the proportions of $\mathrm{Al}$ and $\mathrm{Mg}$ entering the leaching solution were $83 \%$ and $77 \%$, respectively. Al content in the original SIBA sample was $30,425 \mathrm{mg} / \mathrm{kg}$, which was higher than any other elements. This result was similar to the conclusion made by Gorazda et al. (2016), who found that the proportions of $\mathrm{Mg}$ from three types of incinerated ash in solution were all above $50 \%$. It indicated that compounds containing $\mathrm{Mg}$ and $\mathrm{P}$ in the incinerated ash could reacted quickly with $\mathrm{H}_{2} \mathrm{SO}_{4}$. Possible reactions between metal compounds in incinerated ash and $\mathrm{H}_{2} \mathrm{SO}_{4}$ were shown in Equations (2) to (5).

$$
\begin{gathered}
\mathrm{AlPO}_{4}+3 \mathrm{H}^{+} \rightarrow \mathrm{Al}^{3+}+\mathrm{H}_{3} \mathrm{PO}_{4} \\
\mathrm{Al}_{2} \mathrm{O}_{3}+6 \mathrm{H}^{+} \rightarrow 2 \mathrm{Al}^{3+}+3 \mathrm{H}_{2} \mathrm{O} \\
\mathrm{MgO}+2 \mathrm{H}^{+} \rightarrow \mathrm{Mg}^{2+}+\mathrm{H}_{2} \mathrm{O} \\
\mathrm{CaCO}_{3}+2 \mathrm{H}^{+}+\mathrm{SO}_{4}{ }^{2-} \rightarrow \mathrm{CaSO}_{4} \downarrow+\mathrm{H}_{2} \mathrm{CO}_{3}
\end{gathered}
$$

About $50 \%$ of $\mathrm{Ca}$ entered into the solution, indicating that $\mathrm{H}_{2} \mathrm{SO}_{4}$ had an average ability to extract $\mathrm{Ca}$ from SIBA. The reason might be the gypsum formed by $\mathrm{Ca}$ and $\mathrm{H}_{2} \mathrm{SO}_{4}$. Equation (5) described the process. However, $\mathrm{CaSO}_{4}$ would

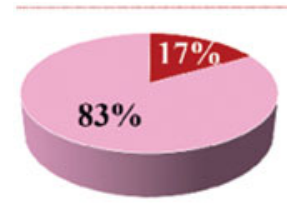

$\mathrm{Al}$

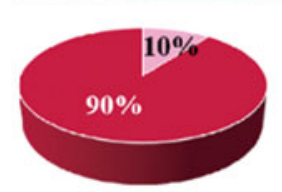

$\mathrm{Zn}$

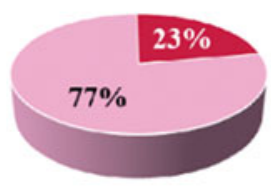

Mg

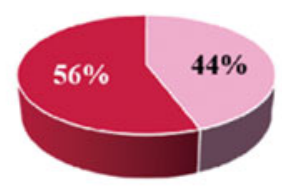

$\mathrm{Ca}$

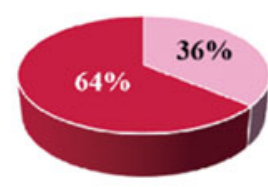

K

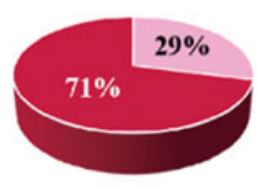

$\mathrm{Cu}$

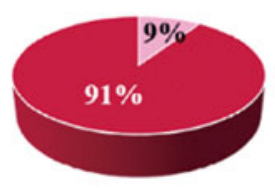

$\mathrm{Fe}$

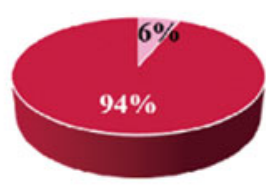

$\mathrm{Pb}$

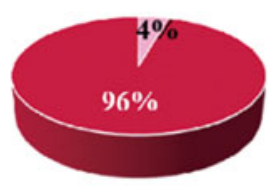

$\mathrm{Cr}$

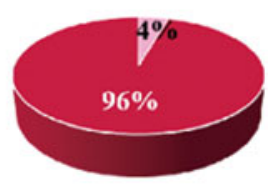

$\mathrm{Ni}$

- Solid residue $=$ Leaching solution

FIG. 4. Metals distribution between the leaching solution and solid residue of SIBA after P extraction. 


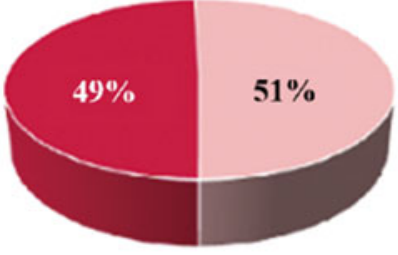

$\mathrm{Cu}$

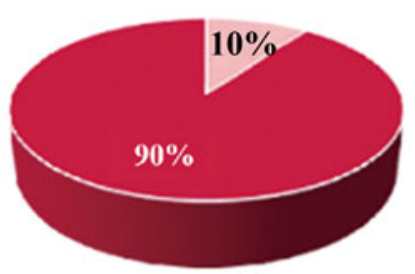

$\mathrm{Zn}$

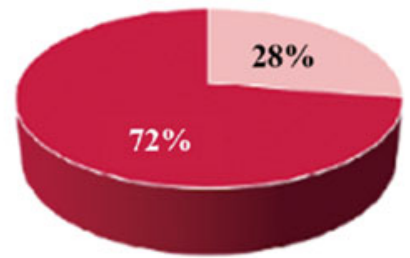

K

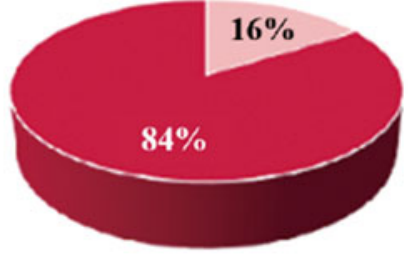

$\mathrm{Fe}$

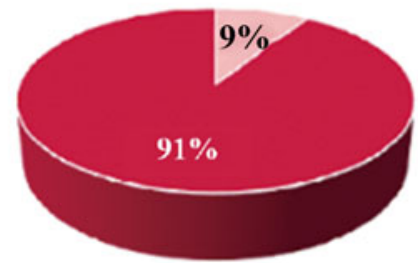

$\mathrm{Ti}$

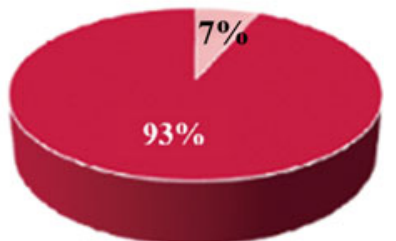

$\mathrm{Ca}$

Solid residue

\section{Leaching solution}

FIG. 5. Metals distribution between the leaching solution and solid residue of SIFA after P extraction.

prevent the further reaction of $\mathrm{H}_{2} \mathrm{SO}_{4}$ and SIBA particles (Cohen, 2009; Fang et al., 2018). While most of $\mathrm{Cu}, \mathrm{Zn}, \mathrm{Pb}$, $\mathrm{Cr}$, and $\mathrm{Ni}$ in SIBA stayed in the solid residue, and showed a low ability to enter the solution. The proportions of them entering into the solution were $29 \%, 10 \%, 6 \%, 4 \%$, and $4 \%$, respectively. It could be inferred that these elements were not easily extracted by $\mathrm{H}_{2} \mathrm{SO}_{4}$ and low content of these elements in the solution.

Metals distribution between the leaching solution and solid residue of SIFA after $P$ extraction. Under optimal experiment conditions, metals distribution between the leaching solution and solid residue of SIFA after $\mathrm{P}$ extraction was shown in Fig. 5. As shown in Fig. 5, 51\% of $\mathrm{Cu}$ entered into the leaching solution. Only $16 \%$ of Fe in SIFA entered into the leaching solution after $\mathrm{H}_{2} \mathrm{SO}_{4}$ extraction. The proportion of Fe in SIBA entering into the leaching solution was $9 \%$ as shown in Fig. 4. Low amount of Fe leaching yields from SIFA and SIBA were favorable to further production of $\mathrm{P}$ fertilizer, because the presence of $\mathrm{Fe}$ increased the viscosity of the leaching solution and changed the color of the $\mathrm{P}$ fertilizer (Gorazda et al., 2016).

Different from SIBA, only $7 \%$ of Ca in SIFA entered into the solution. The reason might be that $\mathrm{Ca}$ has the highest amount comparing with others in SIFA shown in Table 1. At the same time, $\mathrm{Ca}^{2+}$ also reacted with $\mathrm{SO}_{4}{ }^{2-}$ to form $\mathrm{CaSO}_{4}$. Ottosen et al. (2013) also found large amount of gypsum crystals by $\mathrm{H}_{2} \mathrm{SO}_{4}$. Therefore, almost all of Ca still stayed in the solid residue. From this perspective, it suggested that solid residue had the potential to recover $\mathrm{Ca}$.

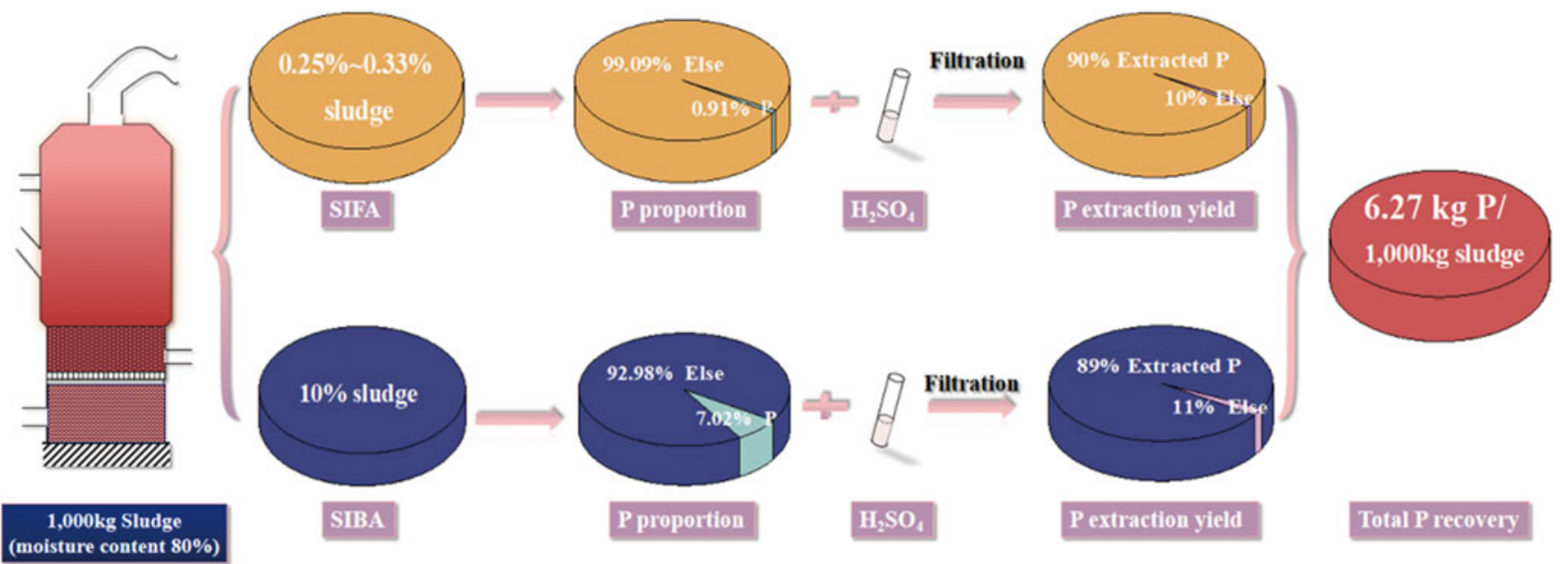

FIG. 6. Phosphorus recovery potential of $1,000 \mathrm{~kg}$ of sludge (moisture content $80 \%$ ). 
Comparison of toxic metals contents between leaching solutions and standards. Using leaching solution for subsequent production of $\mathrm{P}$ fertilizer had strict limits. It is important to detect the toxic metals contents in the leaching solution of SIBA and SIFA. The toxic metals of $\mathrm{Cu}, \mathrm{Zn}, \mathrm{Pb}$, $\mathrm{Cr}$, and $\mathrm{Ni}$ in the leaching solution were strictly restricted by Chinese National standards. The measuring data of the five toxic metals were recorded and compared with the standards of China and USA, as shown in Table 2.

U.S. AAPFCO (2018) set limits for the content of heavy metals in NPK fertilizers with the basic unit of $1 \% \mathrm{P}_{2} \mathrm{O}_{5}$ in Table 2. For example, if a fertilizer product contains $10 \%$ $\mathrm{P}_{2} \mathrm{O}_{5}$, the toxic metal contents of $\mathrm{Zn}, \mathrm{Ni}$, and $\mathrm{Pb}$ should not exceed 4,200, 2,500, and $610 \mathrm{mg} / \mathrm{kg}$ in fertilizer, respectively. Chinese National Standard of CN-GB (2018) offered guidance on thresholds and limits for key pollutants in sludge that poses health risks for agriculture use in Table 2. By comparison, Table 2 showed that $\mathrm{Cu}, \mathrm{Zn}, \mathrm{Pb}, \mathrm{Cr}$, and $\mathrm{Ni}$ in the leaching solution from SIBA and SIFA did not exceed the U.S. AAPFCO and Chinese national regulatory levels in this study. It indicated that leaching solutions of SIBA and SIFA would meet the requirements for the production of $\mathrm{P}$ fertilizers.

\section{$P$ recovery potential of sludge by incineration}

Based on investigations, proportions of SIBA and SIFA mass to wet sludge (moisture content $80 \%$ ) mass were $10 \%$ and $0.25-0.33 \%$, respectively. It indicated that $1,000 \mathrm{~kg}$ of wet sludge could produce about $100 \mathrm{~kg}$ of SIBA and $2.5-$ $3.3 \mathrm{~kg}$ of SIFA through the incineration process. In this study, P contents were 70,200 and $9,100 \mathrm{mg} / \mathrm{kg}$ of SIBA, and in SIFA, respectively. When the optimal experimental condition was carried out (reaction time of $30 \mathrm{~min}, \mathrm{H}_{2} \mathrm{SO}_{4}$ dosage of $12 \mathrm{mmol}$, the reaction temperature of $25^{\circ} \mathrm{C}$, and a ratio of leachate/solid ash of 35), $\mathrm{P}$ extraction yields were $89 \%$ from SIBA and $90 \%$ from SIFA. Based on the obtained extraction yields, it would be calculated that $6.25 \mathrm{~kg}$ of P was extracted from $100 \mathrm{~kg}$ of SIBA and $0.02 \mathrm{~kg}$ of P was extracted from 2.5 to $3.3 \mathrm{~kg}$ of SIFA. Combined with the investigations, an approximate estimate was made. A total of $6.27 \mathrm{~kg}$ of $\mathrm{P}$ would be extracted from $1,000 \mathrm{~kg}$ of wet sludge. $\mathrm{P}$ extraction process of SIBA and SIFA by $\mathrm{H}_{2} \mathrm{SO}_{4}$ was drawn in Fig. 6 .

\section{Conclusions}

The effects of $\mathrm{P}$ extraction from SIBA and SIFA were compared. P contents of SIBA and SIFA were 70,200 and $9,100 \mathrm{mg} / \mathrm{kg}$, respectively. It indicated that SIBA had greater potential for $\mathrm{P}$ recovery than SIFA. With the depletion of phosphate resources, SIFA could also be used for $P$ recovery. The reaction temperature was an important factor in $\mathrm{P}$ extraction. Using $\mathrm{H}_{2} \mathrm{SO}_{4}$ as the extracting agent, $\mathrm{P}$ extraction yields were obtained more than $98 \%$ for both SIBA and SIFA at $45^{\circ} \mathrm{C}$. Taking consideration of the costs, $89 \%$ and $90 \%$ of $\mathrm{P}$ recovered from SIBA and SIFA under the optimal conditions of the reaction time of $30 \mathrm{~min}, \mathrm{H}_{2} \mathrm{SO}_{4}$ dosage of $12 \mathrm{mmol}$, the reaction temperature of $25^{\circ} \mathrm{C}$, and a ratio of leachate/solid ash of 35. The contents of $\mathrm{Cu}, \mathrm{Zn}, \mathrm{Pb}, \mathrm{Cr}$, and $\mathrm{Ni}$ in the leaching solution from SIBA and SIFA met the standards of production of $\mathrm{P}$ fertilizer. The leaching solution was suitable for $\mathrm{P}$ fertilizer production. Based on investigations and calcula- tions, a total of $6.27 \mathrm{~kg}$ of $\mathrm{P}$ would be extracted from $1,000 \mathrm{~kg}$ of sludge $(6.25 \mathrm{~kg}$ of $\mathrm{P}$ was extracted from SIBA and $0.02 \mathrm{~kg}$ of $\mathrm{P}$ was extracted from SIFA).

\section{Author Disclosure Statement}

No competing financial interests exist.

\section{Funding Information}

This work was supported by the Science and Technology Major Projects of Sichuan Province "Technology Integration and Demonstration of Stability and Standard Achievement in Urban Sewage Treatment Plant' (No. 2019YFS0501) and the "Special Funds for Basic Research Funding of Central Colleges and Universities.',

\section{References}

Adam, C., Peplinski, B., Michaelis, M., Kley, G., and Simon, F.G. (2009). Thermochemical treatment of sewage sludge ashes for phosphorus recovery. Waste Manage. 29, 1122.

American Public Health Association (APHA), American Water Works Association (AWWA), and Water Environment Federation (WPCF). (2005). Standard Methods for the Examination of Water and Wastewater, 20th ed. Washington, DC: American Public Health Association.

Association of American Plant Food Control Officials (U.S. AAPFCO). Statement of uniform interpretation and policy (SUIP)\#25-The heavy metal rule [EB/OL]. 2018. Available at: www.aapfco.org/rules.html Accessed May 23, 2020.

Atienza-martínez, M., Gea, G., Arauzo, J., Kersten, S.R.A., and Kootstra, M.J. (2014). Phosphorus recovery from sewage sludge char ash. Biomass Bioenerg. 65, 42.

Biswas, B.K., Inoue, K., Harada, H., Ohto, K., and Kawakitaeta, H. (2009). Leaching of phosphorus from incinerated sewage sludge ash by means of acid extraction followed by adsorption on orange waste gel. J. Environ. Sci. 21, 1753.

$\mathrm{CN}-\mathrm{GB}, 2009$. Disposal of sludge from municipal wastewater treatment plant-Quality of sludge for co-landfilling (GB/T 23485.2-2009).

CN-GB, 2018. Control standards of pollutants in sludge for agriculture use (GB 4284.3-2018).

Cohen, Y. (2009). Phosphorus dissolution from ash of incinerated sewage sludge and animal carcasses using sulphuric acid. Environ. Technol. 30, 1215.

Donatello, S., Freeman-Pask, A., Tyrer, M., and Cheeseman, C.R. (2010). Effect of milling and acid washing on the pozzolanic activity of incinerator sewage sludge ash. Cement Concrete Comp. 32, 54.

Dong, B., Liu, X., Dai, L., and Dai, X. (2013). Changes of heavy metal speciation during high-solid anaerobic digestion of sewage sludge. Bioresour. Technol. 131, 152.

Fang, L., Li, J., Guo, M., Cheeseman, C. Tsang, D., Donatello, S., and Poon, C. (2018). Phosphorus recovery and leaching of trace elements from incinerated sewage sludge ash (ISSA). Chemosphere 193, 278.

Gorazda, K., Tarko, B., Wzorek, Z., Nowak, A.K., Kulczycka, J., and Henclik, A. (2016). Characteristic of wet method of phosphorus recovery from polish sewage sludge ash with. Open Chem. 14, 37.

Herzel, H., Krüger, O., Hermann, L., and Adam, C. (2016). Sewage sludge ash-A promising secondary phosphorus source for fertilizer production. Sci. Total Environ. 542, 1136. 
Huang, Y., Li, H., Jiang, Z., Yang, X.J., and Chen, Q. (2018). Migration and transformation of sulfur in the municipal sewage sludge during disposal in cement kiln. Waste Manage. 77, 537.

Karamalidis, A.K., and Voudrias, E.A. (2009). Leaching and immobilization behavior of $\mathrm{Zn}$ and $\mathrm{Cr}$ from cement-Based stabilization/solidification of ash produced from incineration of refinery oily sludge. Environ. Eng. Sci. 26, 81.

Kleemann, R., Chenoweth, J., Clift, R., Morse, S., Pearce, P., and Saroj, D. (2017). Comparison of phosphorus recovery from incinerated sewage sludge ash (ISSA) and pyrolysed wastewater sludge char (PSSC). Waste Manage. 60, 201.

Kurt, U., Gonullu, M.T., Ilhan, F., and Varinca, K. (2008). Treatment of domestic wastewater by electrocoagulation in a Cell with Fe-Fe electrodes. Environ. Eng. Sci. 25, 153.

Lee, M., and Kim, D.J. (2017). Identification of phosphorus forms in sewage sludge ash during acid pre-treatment for phosphorus recovery by chemical fractionation and spectroscopy. J. Ind. Eng. Chem. 51, 64.

Li, R., Zhang, Z., Li, Y., Teng, W., Wang, W., and Yang, T. (2015). Transformation of apatite phosphorus and non-apatite inorganic phosphorus during incineration of sewage sludge. Chemosphere 141, 57.

Li, X., Chen, L., Mei, Q., Dong, B., Dai X., Ding, G., and Eddy, Y.Z. (2018). Microplastics in sewage sludge from the sewage treatment plants in China. Water Res. 142, 75.

Liang, S., Chen, H., Zeng, X., Li, Z., Yu, W., Xiao, K., Hu, J., Hou, H., Liu, B., Tao, S., and Yang, J. (2019). A comparison between sulfuric acid and oxalic acid leaching with subsequent purification and precipitation for phosphorus recovery from sewage sludge incineration ash. Water Res. 159, 242.

Lundin, M., Olofsson, M., Pettersson, G.J., and Zetterlund, H. (2004). Environmental and economic assessment of sewage sludge handling options. Resour. Conserv. Recycl. 41, 255.

Mahon, A.M., O'Connell, B., Healy, M.G., O'Connor, I., Officer, R., Nash, R., and Morrison, L. (2017). Microplastics in sewage sludge: Effects of treatment. Environ. Sci. Technol. 51,810 .

Mattenberger, H., Fraissler, G., Brunner, T., Herk, P., Hermann, L., and Obernberger, I. (2008). Sewage sludge ash to phosphorus fertiliser: variables influencing heavy metal removal during thermochemical treatment. Waste Manage. 28, 2709.

Meng, X., Huang, Q., Gao, H., Tay, K., and Yan, J. (2018). Improved utilization of phosphorous from sewage sludge (as Fertilizer) after treatment by Low-Temperature combustion. Waste Manage. 80, 349.

Milieu, L., WRc, and RPA. (2010). Study on the environmental, economic and social impacts of the use of sewage sludge on land, contract DB ENV.G.4/ETU/2008/0076r, s.1.: s.n.

Murakami, T., Suzuki, Y., Nagasawa, H., Yamamoto, T., Koseki, T., Hirose, H., and Okamoto, S. (2009). Combustion characteristics of sewage sludge in an incineration plant for energy recovery. Fuel Process. Technol. 90, 778.

Nie, D., Xue, A., Zhu, M., Zhang, Y., and Cao, J. (2019). Separation and recovery of associated rare earths from the Zhijin phosphorite using hydrochloric acid. J. Rare Earths 37, 443.

Nowak, B., Perutka, L., Aschenbrenner, P., Kraus, P., Rechberger, H., and Winter, F. (2011). Limitations for heavy metal release during thermo-chemical treatment of sewage sludge ash. Waste Manage. 31, 1285.

Ottosen, L.M., Jensen, P.E., and Kirkelund, G.M. (2016). Phosphorous recovery from sewage sludge ash suspended in water in a two-compartment electrodialytic cell. Waste Manage. 51, 142.

Ottosen, L.M., Kirkelund, G.M., and Jensen, P.E. (2013). Extracting phosphorous from incinerated sewage sludge ash rich in iron or aluminum. Chemosphere 91, 963.

Parés, V.R., Jensen, P.E., Ottosen, L.M., Ahrenfeldt, J., and Hauggaard-Nielsen, H. (2017). Sequential electrodialytic recovery of phosphorus from low-reaction temperature gasification ashes of chemically precipitated sewage sludge. Waste Manage. 60, 211.

Saleh, B.Z.A., Li, R., Li, Y., Gao, H., Sema, T., Teng, W., Kumar, S., and Liang, Z. (2018). New advancement perspectives of chloride additives on enhanced heavy metals removal and phosphorus fixation during thermal processing of sewage sludge. J. Clean Prod. 188, 185.

Sano, A., Kanomata, M., Inoue, H., Sugiura, N., Xu, K.Q., and Inamori, Y.H. (2012). Extraction of raw sewage sludge containing iron phosphate for phosphorus sewage sludge containing iron phosphate for phosphorus recovery. Chemosphere 89, 1243.

Shiba, N.C., and Ntuli, F. (2017). Extraction and precipitation of phosphorus from sewage sludge. Waste Manage. 60, 191.

Wang, Q., Li, J., Tang, P., Fang, L., and Poon, C.S. (2018). Sustainable reclamation of phosphorus from incinerated sewage sludge ash as value-added struvite by chemical extraction, purification and crystallization. J. Clean Prod. 181, 717.

$\mathrm{Xu}, \mathrm{H} ., \mathrm{He}, \mathrm{P} ., \mathrm{Gu}, \mathrm{W} ., \mathrm{Wang}, \mathrm{G}$., and Shao, L. (2012). Recovery of phosphorus as struvite from sewage sludge ash. $J$. Environ. Sci. 24, 1533.

Xu, L.G., Bemd, L., Zhang, X.G., Zheng, W., and Meng, Q.T. (2014). Trace element distribution in black shales from the kunyang phosphorite deposit and its geological significances. Acta Petrol. Sin. 30, 1817.

Yang, G., Zhang, G., and Wang, H. (2015). Current state of sludge production, management, treatment and disposal in China. Water Res. 78, 60.

Yvonne, L.W., Cheng, N.W., Ee, W.B.S., Teo, S.L.M., Sivananthan, G., Hun, B.G., Sik, Y.O., and Wang, C.H. (2018). Evaluation of sewage sludge incineration ash as a potential land reclamation material. J. Hazard. Mater. 357, 63. 